\title{
29. GEOCHEMICAL AND OPTICAL STUDY OF ORGANIC MATTER IN SOME PLEISTOCENE AND PLIOCENE SEDIMENT FROM THE GULF OF CALIFORNIA: LEG 64, HOLES 474 TO $481 A^{1}$
}

\author{
G. Deroo, J. P. Herbin, J. Roucaché, and J. P. Boudou, Institut Français du Pétrole, \\ Synthèses Géologiques et Géochimie, Rueil-Malmaison, France \\ and \\ P. Robert, S. Jardiné, and P. Marestang, Societé Nationale Elf-Aquitaine, \\ Centre Recherches Boussens, Saint-Martory, France
}

\begin{abstract}
Pleisto-Pliocene hemipelagic and diatomaceous mud was recovered from Deep Sea Drilling Project (DSDP) Sites 474 through 481 in the Gulf of California. The organic matter is mostly marine and mainly derived from diatomaceous protoplasm. We found some continental organic matter in sediments near the bottom basalts or near dolerites (Holes $474 \mathrm{~A}$ and 478 ). The organic matter in most of the samples is in an early stage of evolution.
\end{abstract}

\section{INTRODUCTION}

This chapter describes geochemical analyses of organic matter in the Pleisto-Pliocene sediment in DSDP Holes 474A, 475, 476, 478, 479, and 481-481A above basalt or dolerite sills. We describe a pyrolysis assay and a humic extraction of eight samples, mostly from Hole 479. We performed both procedures before preparing and analyzing the samples for kerogen. We conducted an optical study on the same material. The application of reflected light and fluorescence to the whole rock produced no chemical effects. We also conducted a palynological examination of acid-treated samples.

\section{SAMPLES}

In the Cabo San Lucas area, we recovered nine Pleistocene-to-early Pliocene samples from Holes 474A, 475, and 479 . The sediment from Hole 474A comprises turbidite, silt, and claystone. Hole 475 and Hole 476 are composed of hemipelagic and diatomaceous mud.

In the Guaymas Basin, we obtained 27 samples of Quaternary-Pleistocene sediment from Hole 479 and, to the south, from Holes 478,481 , and $481 \mathrm{~A}$. The hemipelagic-diatomaceous mud in the latter holes is similar to that in Hole 479. The sediment in Holes 478 and 481A for the upper series varies from diatomaceous ooze to mudstone with some turbidites. The lower series includes laminations in Hole 478 and mudflows in Hole 481A. In Holes 478 and $481 \mathrm{~A}$, some dolerite sills are interlayered with the sediment.

\section{GEOCHEMICAL STUDY}

\section{METHOD}

The analytical procedures are outlined in Figure 1. Using a Leco apparatus, we determined organic carbon in acid-treated samples. We conducted a pyrolysis assay on raw samples with a Rock Eval (Espitalié et al., 1977). With chloroform, we extracted equivalent parts of

\footnotetext{
${ }^{1}$ Curray, J. R., Moore, D. G., et al., Init. Repts. DSDP, 64: Washington (U.S. Govt. Printing Office).
}

samples. The humic compounds were then isolated and their carbon content analyzed with a carmhograph WOSTHOFF apparatus before the kerogen was prepared (Huc et al., 1978). Carbon content was also analyzed in the hydrolyzable fraction obtained after $\mathrm{HCl}(6 \mathrm{~N})$ treatment on humin. We then performed elemental analysis on the kerogen concentrate.

\section{Results}

\section{Mineral Carbon (Table 1)}

Low mineral carbon $(0.24-1.64$ wt. $\%$ i.e., $2-14 \%$ carbonates) characterizes the samples from various holes.

\section{Organic Carbon (Table 1)}

In the Cabo San Lucas area, the organic carbon range is 1.63 to $3.00 \mathrm{wt} . \%$, except for samples near eruptive series, where the content decreases $(0.89$ and 1.22 in Holes $474 \mathrm{~A}$ and 476 , respectively).

In the Guaymas Basin, we also found the lowest content in the bottom samples (1.33 in Hole 479 and 0.64 in Hole 478). But the other samples reveal a 2.40 -to- 4.00 range in Hole 479 and 1.52 to 2.44 in Hole 478 . We observed a similar range $(0.97-2.27)$ in Holes 481 and 481A, which lie to the north of Site 478 .

\section{Pyrolysis Assay on Raw Samples (Table 1)}

The method of pyrolysis described in Espitalié et al. (1977), using a Rock Eval apparatus, defines three types of kerogen (Tissot et al., 1974), which can be used to characterize organic matter in ancient sediments.

According to the hydrogen index (HI)-versus-oxygenindex (OI) diagram (Fig. 2A, B), some samples are near the initial evolution path of kerogen Type III and can be considered immature continental organic matter. Some correspond to the bottom sediments in Holes 474A and 478 and the top of the mudflows in Hole 481A. The data for the other samples are relatively dispersed $(\mathrm{HI}=$ 127-450; OI $=57-244$ ) and are not near Reference Paths I, II, or III. This distribution is common for immature material. Considerable oxygenated molecules in such material contribute to rich oxygen indexes. When 


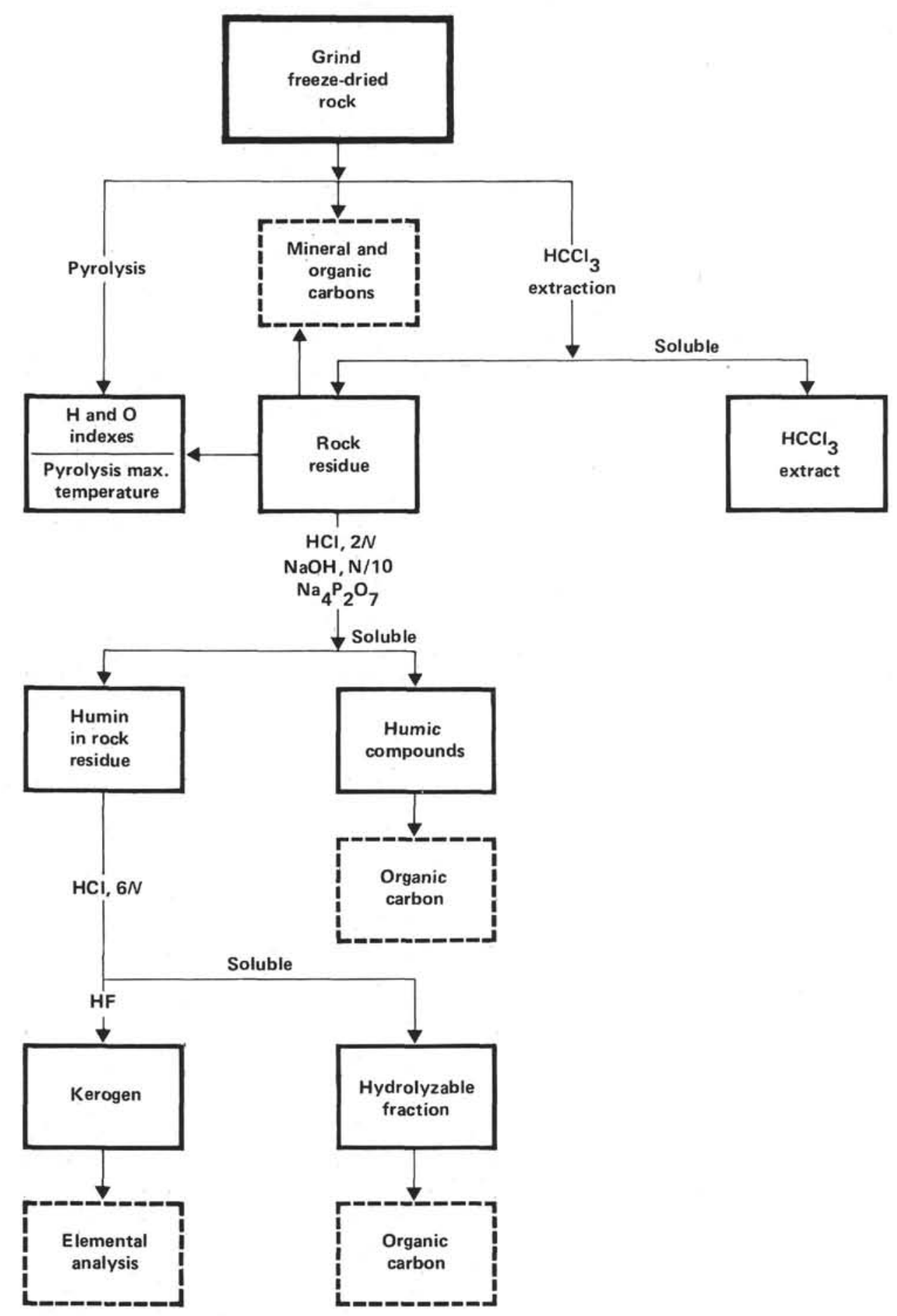

Figure 1. Schematic analytical processes.

diagenesis increases, defunctionalization modifies this organic material so that the oxygen indexes decrease and tend to reach the range of the reference paths of ancient sediments.

In a pyrolysis assay, the temperature at the top of the pyrolysis peak (Table 1) corresponds to the immature oil zone in the 400 -to- $440^{\circ} \mathrm{C}$ range, to the main oil zone or mature zone from 440 to $460^{\circ} \mathrm{C}$, and to the cracking or gas zone beyond $460^{\circ} \mathrm{C}$. The samples can be assigned to the early stages of the immature zone. A 418 -to- $-423^{\circ} \mathrm{C}$ range occurs in nearly all Cabo San Lucas samples and a 403-to- $-423^{\circ} \mathrm{C}$ range occurs in the Guaymas Basin samples, except for the deepest sample from Holes 478 and 479 with temperatures of 428 and $426^{\circ} \mathrm{C}$, respectively. The Section 481A-13-6 sample has a maximum pyrolysis temperature beyond the $550^{\circ}$ final temperature for pyrolysis assay. This must be caused by ancient, reworked, overmatured material. 
Table 1. Data from carbon and pyrolysis assays on raw samples, Leg 64 .

\begin{tabular}{|c|c|c|c|c|c|c|c|c|c|}
\hline $\begin{array}{c}\text { Sample } \\
\text { (interval in } \mathrm{cm} \text { ) }\end{array}$ & $\begin{array}{l}\text { Sub-bottom } \\
\text { Depth } \\
\text { (m) }\end{array}$ & $\begin{array}{l}\text { Mineral } \\
\text { Carbon } \\
\text { (wt. } \% \text { ) }\end{array}$ & $\begin{array}{c}\text { Carbonates } \\
\text { (wt. \%) }\end{array}$ & $\begin{array}{l}\text { Organic } \\
\text { Carbon } \\
\text { (wt.\%) }\end{array}$ & $\begin{array}{c}\text { Hydrogen } \\
\text { Index } \\
\text { (mg HC/ } \\
\text { g org. C) }\end{array}$ & $\begin{array}{c}\text { Oxygen } \\
\text { Index } \\
\text { (mg CO} 2 / \\
\mathrm{g} \text { org. } \mathrm{C} \text { ) }\end{array}$ & $\begin{array}{l}\text { Hydrogen } \\
\text { Index } \\
\text { (mg HC/ } \\
\text { g rock) }\end{array}$ & $\begin{array}{c}\text { Oxygen } \\
\text { Index } \\
\text { (mg CO} 2 / \\
\text { g rock) }\end{array}$ & $\begin{array}{c}\text { Pyrolysis } \\
\text { Temperature } \\
\left({ }^{\circ} \mathrm{C}\right)\end{array}$ \\
\hline \multicolumn{10}{|l|}{ Hole 479} \\
\hline $3-2,112-130$ & 16.12 & 0.58 & 4.8 & 3.03 & 362 & 207 & 10.96 & 6.28 & 411 \\
\hline $5-3,125-139$ & 36.25 & 0.70 & 5.8 & 2.88 & 275 & 169 & 7.93 & 4.88 & 421 \\
\hline $7-5,135-140$ & 57.85 & 0.46 & 3.8 & 2.56 & 348 & 118 & 8.92 & 3.02 & 403 \\
\hline $9-2,125-130$ & 82.75 & 1.48 & 12.3 & 2.62 & 335 & 158 & 8.77 & 4.15 & 404 \\
\hline $13-1,110-130$ & 109.60 & 0.96 & 8.0 & 2.98 & 391 & 147 & 11.65 & 4.37 & 409 \\
\hline $15-5,123-129$ & 135.23 & 0.38 & 3.2 & 3.14 & 418 & 114 & 13.13 & 3.58 & 419 \\
\hline $17-5,120-140$ & 154.20 & 0.16 & 1.3 & 2.40 & 391 & 112 & 9.38 & 2.69 & 411 \\
\hline $19-5,110-115$ & 183.10 & 0.72 & 6.0 & 2.58 & 307 & 126 & 7.92 & 3.25 & 411 \\
\hline $22-5,134-140$ & 201.34 & 0.36 & 3.0 & 2.93 & 332 & 107 & 9.74 & 3.13 & 416 \\
\hline $27-4,120-140$ & 246.70 & 0.62 & 5.2 & 2.54 & 346 & 120 & 8.80 & 3.04 & 410 \\
\hline $29-5,134-140$ & 267.34 & 0.24 & 2.0 & 3.08 & 314 & 67 & 9.67 & 2.07 & 410 \\
\hline $34-5,125-130$ & 313.75 & 0.68 & 5.7 & 3.30 & 352 & 100 & 11.63 & 3.30 & 416 \\
\hline $37-5,130-150$ & 342.30 & 0.26 & 2.2 & 3.71 & 445 & 63 & 16.51 & 2.32 & 413 \\
\hline $39-4,110-115$ & 362.60 & 0.32 & 2.7 & 4.00 & 450 & 57 & 18.01 & 2.27 & 410 \\
\hline $43-1,130-135$ & 393.30 & 1.20 & 10.0 & 2.75 & 392 & 95 & 10.78 & 2.62 & 416 \\
\hline $47-4,110-130$ & 433.60 & 1.64 & 13.7 & 1.33 & 201 & 179 & 2.67 & 2.38 & 426 \\
\hline \multicolumn{10}{|l|}{ Hole 481} \\
\hline $8-2,125-130$ & 33.75 & 1.04 & 8.7 & 1.93 & 344 & 488 & 6.63 & 9.41 & 421 \\
\hline \multicolumn{10}{|l|}{ Hole $481 \mathrm{~A}$} \\
\hline $8-2,110-117$ & 111.60 & 0.90 & 7.5 & 2.21 & 321 & 233 & 7.09 & 5.15 & 418 \\
\hline $13-6,0-5$ & 162.50 & 1.14 & 9.5 & 0.97 & 17 & 44 & 0.17 & 0.43 & \\
\hline $24-5,110-116$ & 267.10 & 1.00 & 8.3 & 1.37 & 96 & 185 & 1.31 & 2.54 & 423 \\
\hline $30-5,133-140$ & 334.33 & 1.52 & 12.7 & 2.27 & 292 & 137 & 6.63 & 3.12 & 415 \\
\hline \multicolumn{10}{|l|}{ Hole 474A } \\
\hline $7-2,110-115$ & 222.60 & 0.68 & 5.7 & 1.63 & 150 & 155 & 2.45 & 2.53 & 423 \\
\hline $21-6,48-53$ & 352.98 & 1.62 & 13.5 & 1.65 & 222 & 160 & 3.66 & 2.64 & 421 \\
\hline $32-2,145-140$ & 452.95 & 0.98 & 8.2 & 2.04 & 216 & 112 & 4.41 & 2.28 & 430 \\
\hline $41-3,120-125$ & 539.20 & 0.88 & 7.3 & 0.89 & 64 & 245 & 0.57 & 2.18 & 421 \\
\hline \multicolumn{10}{|l|}{ Hole 475} \\
\hline $6 \cdot 5,120-129$ & 52.20 & 1.04 & 8.7 & 2.27 & 199 & 158 & 4.51 & 3.58 & 418 \\
\hline $16-2,120-130$ & 142.70 & 0.66 & 5.5 & 2.49 & 302 & 90 & 7.53 & 2.24 & 422 \\
\hline \multicolumn{10}{|l|}{ Hole 476} \\
\hline $3-4,120-127$ & 25.70 & 0.84 & 7.0 & 3.08 & 322 & 160 & 9.92 & 4.94 & 419 \\
\hline $11-4,110-116$ & 101.60 & 0.76 & 6.3 & 2.30 & 234 & 142 & 5.39 & 3.27 & 421 \\
\hline $19-1,140-145$ & 173.40 & 0.44 & 3.7 & 1.22 & 199 & 125 & 2.43 & 1.53 & 421 \\
\hline \multicolumn{10}{|l|}{ Hole 478} \\
\hline $7-5,120-140$ & 58.20 & 1.04 & 8.7 & 1.89 & 127 & 244 & 2.40 & 4.61 & 420 \\
\hline $11-4,120-125$ & 93.70 & 0.74 & 6.2 & 1.98 & 222 & 179 & 4.40 & 3.55 & 420 \\
\hline $14-4,120-127$ & 122.70 & 0.92 & 7.7 & 2.44 & 347 & 190 & 8.46 & 4.63 & 412 \\
\hline $17-4,139-145$ & 151.89 & 1.00 & 8.3 & 1.52 & 88 & 213 & 1.34 & 3.23 & 423 \\
\hline $28-4,120-125$ & 247.70 & 0.84 & 7.0 & 2.43 & 308 & 116 & 7.49 & 2.81 & 408 \\
\hline $35-5,110-116$ & 305.10 & 1.12 & 9.3 & 0.64 & 91 & 191 & 0.58 & 1.22 & 428 \\
\hline
\end{tabular}

\section{Humic Compounds and Hydrolyzable Fraction of Humin}

In Hole 479, the organic carbon in the hydrolyzable fraction of humin related to the weight of rock or to the total organic carbon, shows a decrease with depth (Fig. $3 \mathrm{~A}, \mathrm{~B})$. The variation may be caused by diagenesis.

In the same hole, a low proportion of the total carbon (15-5\%) belongs to the humic fractions (Table 2). Huc and Durand (1977) showed that Type III humic fractions revealed a larger proportion (30\% and more) of the total organic carbon than Types I and II $(<10 \%)$ when maturation corresponded to a 0.35 -to- 0.45 reflectance range. If we extend this observation to the lower stages of maturation, the humic compounds in Hole 479 would be related to Type I or II material. A $36.9 \%$ content for Section 478-7-5 would indicate a Type III humic fraction.

\section{Kerogen Fraction}

Elemental analysis of the kerogen concentrate from Section 479-13-1 (Table 3) was inconclusive because of a large amount $(>50 \%)$ of nonorganic material, mainly pyrite. We plotted other data on a Van Krevelen dia- gram (Fig. 4) and compared them to the three reference evolution paths for Types I, II, and III kerogens of ancient sediment (Tissot et al., 1974), deducing a relative homogeneity from the low dispersion of the data. The samples are immature and occur near the beginning of the evolution paths. Thus, to identify kerogens they must be compared with material in the earliest stage of diagenesis. Accordingly, we selected representative marine material from Orgon III (Debyser et al., 1979), cored in a profile off northern Mauritania, and a typical huminolignitic sediment from the present Mahakam Delta in eastern Kalimantan.

We also examined some more mature samples of about 0.45 reflectance (Huc and Durand, 1977) from Reference Paths II and III. Compared to the previous reference samples, the kerogens appear to be on the reference trend of early, immature, Type II material, though the $\mathrm{H} / \mathrm{C}$ ratio is lower than in Reference Path II. It can be explained as a mixture of Type II kerogen with some material of low $\mathrm{H} / \mathrm{C}$ ratio derived from a more oxygenated Type II or Type III material-or even from a residual type (Tissot et al., 1979). Moreover, a decrease of the $\mathrm{O} / \mathrm{C}$ ratio with increasing depth for the Hole 479 samples is apparent on the diagram (Fig. 4) 

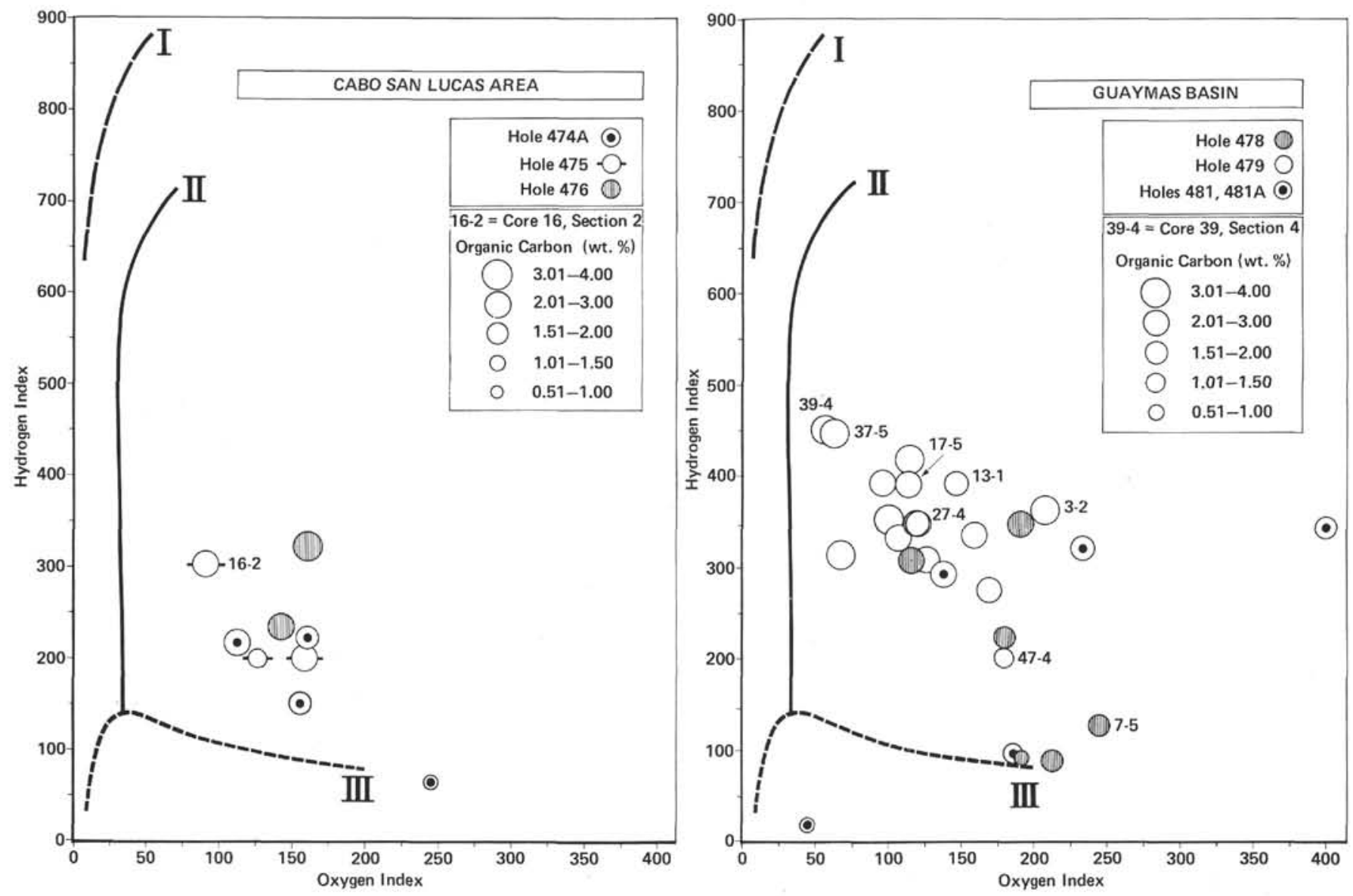

Figure 2. Pyrolysis assays and hydrogen and oxygen indexes, Cabo San Lucas and Guaymas Basin areas.

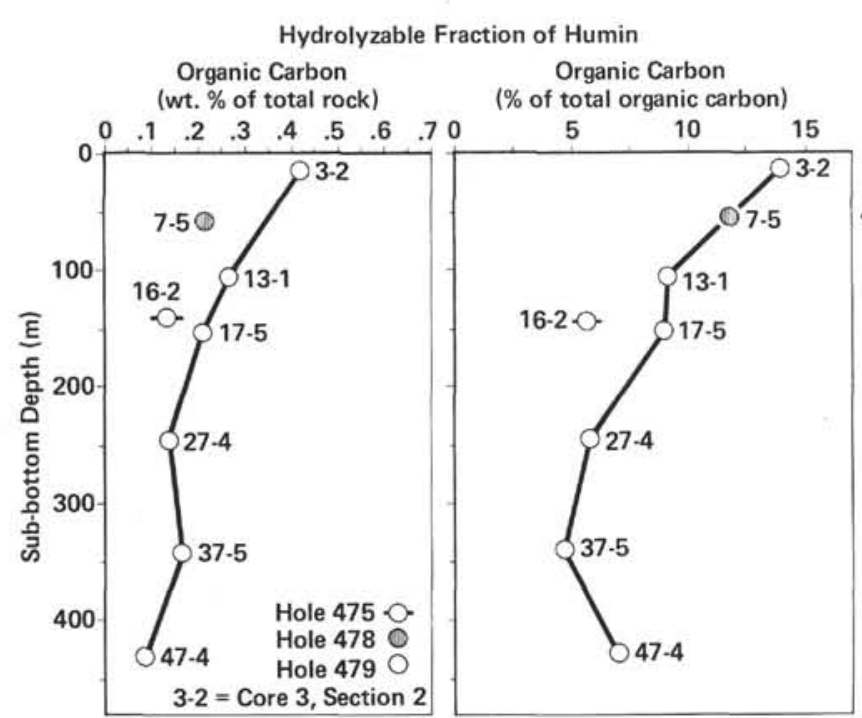

Figure 3. Organic carbon in hydrolyzable fraction of humin versus depth.

and is regular in Figure 5. This decrease depends on diagenesis and probably corresponds to a loss of oxygen in molecules of immature material.

Data for the eight samples discussed in the preceding paragraph indicate the area where most of the other
Table 2. Organic carbon content of humic compounds and hydrolyzable fraction.

\begin{tabular}{|c|c|c|c|c|c|c|}
\hline \multirow[b]{2}{*}{$\begin{array}{c}\text { Sample } \\
\text { (interval in cm) }\end{array}$} & \multirow{2}{*}{$\begin{array}{l}\text { Sub-bottom } \\
\text { Depth } \\
\text { (m) }\end{array}$} & \multirow{2}{*}{$\begin{array}{c}\text { Total } \\
\text { Organic } \\
\text { Carbon } \\
\text { (wt. } \% \text { ) }\end{array}$} & \multicolumn{2}{|c|}{ Humic Compounds } & \multicolumn{2}{|c|}{$\begin{array}{l}\text { Hydrolyzable Fraction } \\
(\mathrm{HCl}, 6 N)\end{array}$} \\
\hline & & & $\begin{array}{c}\text { Carbon } \\
\text { (\% of rock) }\end{array}$ & $\begin{array}{l}\text { Humic C } \\
\text { Total C (\%) }\end{array}$ & $\begin{array}{c}\text { Carbon } \\
\text { ( } \% \text { of rock) }\end{array}$ & $\begin{array}{l}\text { Hyd, C V } \text { s. } \\
\text { Total C (\%) }\end{array}$ \\
\hline $475-16-2,120-130$ & 142.70 & 2.49 & 0.36 & 14.5 & 0.14 & 5.5 \\
\hline $478-7 \cdot 5,120-140$ & 58.20 & 1.91 & 0.70 & 36.9 & 0.22 & 11.6 \\
\hline $479 \cdot 3 \cdot 2,112-130$ & 16.12 & 3.04 & 0.46 & 15.2 & 0.42 & 13.8 \\
\hline $479-13-1,110-130$ & 109.60 & 2.99 & 0.13 & 4.2 & 0.27 & 9.1 \\
\hline $479-17-5,120-140$ & 154.20 & 2.40 & 0.24 & 9.9 & 0.21 & 8.9 \\
\hline $479-27-4,120-140$ & 246.70 & 2.54 & 0.32 & 12.6 & 0.14 & 5.6 \\
\hline $479-37-5,130-150$ & 342.30 & 3.71 & 0.20 & 5.3 & 0.17 & 4.5 \\
\hline $479-47-4,110-130$ & 433.60 & 1.33 & 0.08 & 5.7 & 0.09 & 7.0 \\
\hline
\end{tabular}

samples are localized (Fig. 2). Thus we assign a predominant aquatic marine origin and an early stage of maturation to this sample population. Exceptions in the Guaymas Basin correspond to the reworked old material of Section 481A-13-6 and to an immature continental organic matter in the samples from Sections 47817-4, 478-37-5, and 481A-24-5. In the Cabo San Lucas area, the sample from Section $474 \mathrm{~A}-41-3$ is the only continental material.

\section{OPTICAL STUDY}

\section{METHOD}

Reflected Light and Fluorescence. This method deals with whole rock, before chemical treatment, on polished sections (with organic matter concentrated by gravity) and thin sections. Fluorescence enables us to examine both types of sections under reflected fluores- 
Table 3. Kerogen data from elemental analysis.

\begin{tabular}{|c|c|c|c|c|c|c|c|c|c|c|}
\hline \multirow{2}{*}{$\begin{array}{c}\text { Sample } \\
\text { (interval in } \mathrm{cm} \text { ) }\end{array}$} & \multirow{2}{*}{$\begin{array}{l}\text { Sub-bottom } \\
\text { Depth } \\
\text { (m) }\end{array}$} & \multicolumn{2}{|c|}{$\begin{array}{l}\text { Atomic } \\
\text { Ratio }\end{array}$} & \multicolumn{6}{|c|}{ Weight Percentage on Ash-Free Basis } & \multirow{2}{*}{$\begin{array}{l}\text { Ash, Free } \\
\text { of Pyrite } \\
\text { (wt. \%) }\end{array}$} \\
\hline & & $\mathrm{H} / \mathrm{C}$ & $\mathrm{O} / \mathrm{C}$ & C & $\mathrm{H}$ & $\mathrm{N}$ & 0 & $\mathbf{s}$ & $\mathrm{Fe}$ & \\
\hline $475-16-2,120-130$ & 142.70 & 1.16 & 0.23 & 34.91 & 3.38 & 1.96 & 10.97 & 26.39 & 18.05 & 4.34 \\
\hline $4: 8-7-5,120-140$ & 58.20 & 1.22 & 0.21 & 46.29 & 4.71 & 2.41 & 13.42 & 18.47 & 10.46 & 4.24 \\
\hline $479-3-2,112-130$ & 16.12 & 1.23 & 0.24 & 43.17 & 4.41 & 2.32 & 13.81 & 19.37 & 11.95 & 4.97 \\
\hline $479-13-1,110-130$ & 109.60 & 0.94 & 0.49 & 27.19 & 2.13 & 1.35 & 17.82 & 30.80 & 24.97 & - \\
\hline $479-17-5,120-140$ & 154.20 & 1.09 & 0.22 & 40.34 & 3.66 & 2.09 & 11.87 & 22.99 & 14.16 & 4.89 \\
\hline $479-27-4,120-140$ & 246.70 & 1.19 & 0.20 & 41.60 & 4.13 & 2.09 & 11.30 & 20.88 & 12.44 & 7.56 \\
\hline $479-37-5,130-150$ & 342.30 & 1.21 & 0.19 & 52.42 & 5.29 & 2.51 & 13.54 & 14.41 & 9.28 & 2.55 \\
\hline $479-47-4,110-130$ & 433.60 & 1.09 & 0.18 & 36.61 & 3.32 & 2.05 & 8.88 & 26.15 & 19.11 & 3.88 \\
\hline Orgon III,KL 15 & 6.00 & 1.20 & 0.30 & & & & & & & \\
\hline $\begin{array}{l}\text { Palan Island, } \\
\text { Mahakam Delta }\end{array}$ & 0.00 & 1.02 & 0.39 & & & & & & & \\
\hline $\begin{array}{l}\text { Well G.2 } 7.5 \\
\text { Toarcian. Paris Basin }\end{array}$ & 32.50 & 1.16 & 0.14 & & & & & & & \\
\hline $\begin{array}{l}\text { Toarcian, Paris Basin } \\
\text { Jouy aux Arches, } \\
\text { outcrop, Toarcian, } \\
\text { Paris Basin }\end{array}$ & 0.00 & 1.26 & 0.10 & & & & & & & \\
\hline $\begin{array}{l}\text { Well Logbaba 102-1, } \\
\text { Cameroon }\end{array}$ & 775.00 & 0.87 & 0.22 & & & & & & & \\
\hline
\end{tabular}

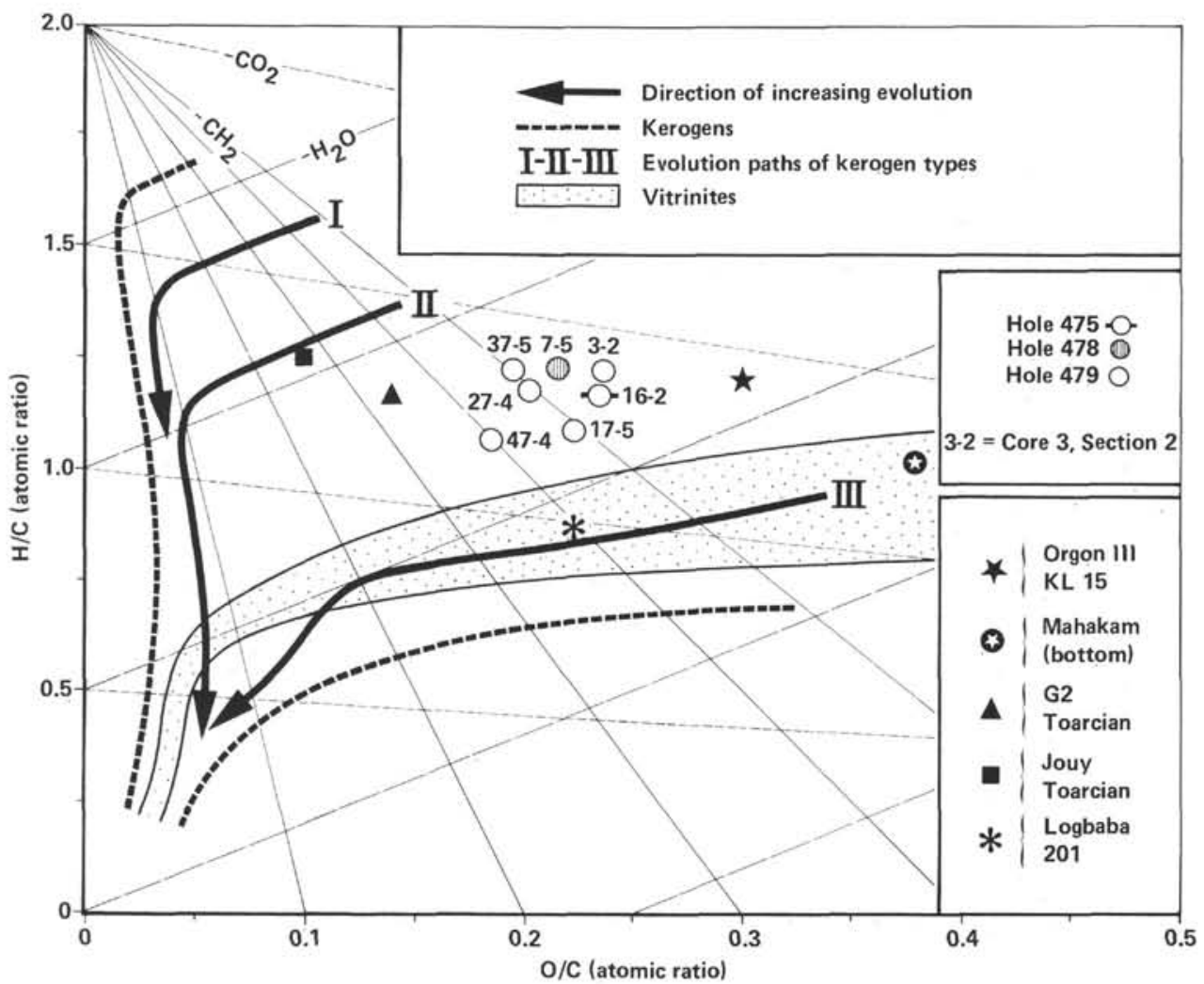

Figure 4. Kerogen: $\mathrm{H} / \mathrm{C}$ and $\mathrm{C} / \mathrm{O}$ diagram.

cent and white light and under transmitted light to recognize the sample in polarized light (Robert, 1979).

We measured vitrinite and bitumen reflectances in the concentrated polished section, using a Leitz Orthoplan microscope photometer in monochromatic $(546 \mathrm{~nm})$ light and oil immersion. We performed fluorescence observations using a Zeiss photomicroscope (excitation range $=350-450 \mathrm{~nm}$; barrier filter at $470 \mathrm{~nm}$ ). A global fluorescence estimate was obtained by a comparison to standards, and the maximum index (5) accorded with the best fluorescent groundmasses (Green River shales). Such an index correlates well with the characteristics of hydrocarbon source rocks. We obtained complementary source rock information from the fading fluorescence (Teichmüller and Ottenjann, 1977), which was applied to the groundmasses and indicated the material's ability to generate hydrocarbon.

Palynological Study. Sample processing was divided into two steps: treatment by $\mathrm{HCL}+\mathrm{HF}$ to obtain the total organic material (TOM in Fig. 6) and treatment with $\mathrm{HNO}_{3}(25 \%$ for $15 \mathrm{~min}$.) and gravity separation with alcohol-bromide to obtain insoluble organic material (IOM in Fig. 6). These two steps allowed us to estimate the degradation of organic material from light-oxidation and the dissolution of soluble constituents.

We summarize the observations on transmitted light in Figure 6 as follows:

1) Percentage (of slide surface) of the various particles constituting the palynofacies;

2) Thermal alteration index (TAI) estimated on the color and transparency of the pollen grains and dinoflagellates.

\section{Results}

\section{Site 479}

Hole 479 comprises early-to-late Pleistocene sediment. We studied six samples from Cores $3,13,17,27,37$, and 


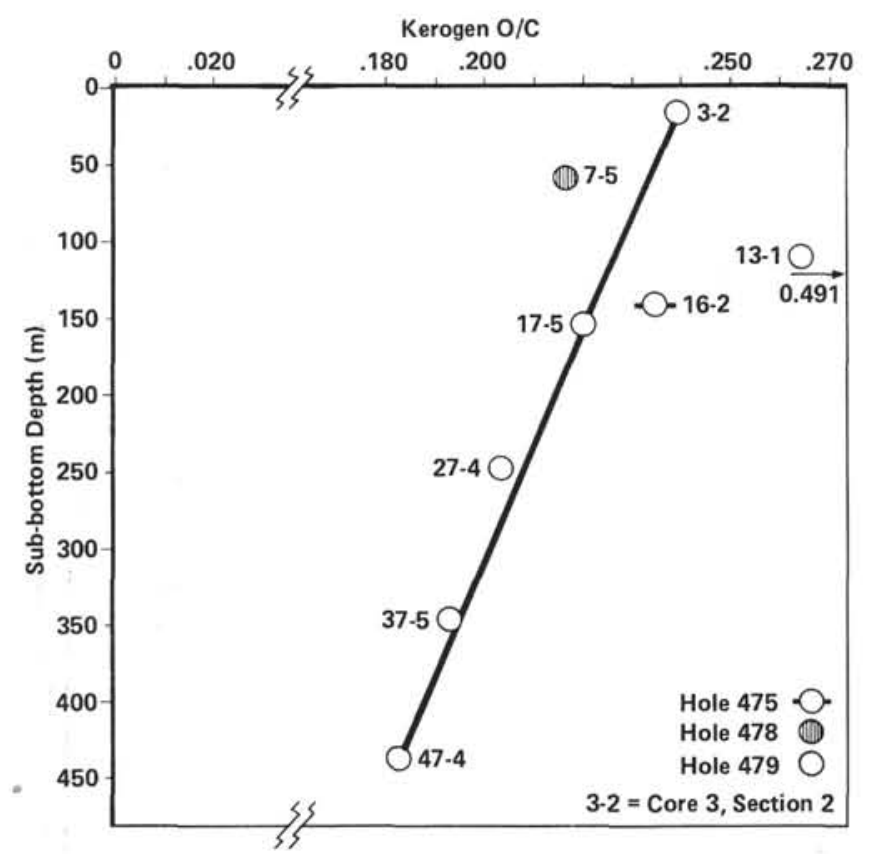

Figure 5. Kerogen: variations with depth of $\mathrm{O} / \mathrm{C}$ ratio.

47. The locations appear in Figure 1 of Simoneit's introduction to shore-based organic geochemistry (this volume), and the vertical positions are presented in Table 1. The main results are given in Figure 6.

On the whole, vitrinite (huminite) is rare, with maximum reflectance values of $0.35 \%$ in Core 27; some bitumens occur at the same level $\left(R_{\mathrm{o}}=0.1-0.3 \%\right)$ but are rare in the rest of the hole.

Fluorescence is active and is quite strong in some samples and indicates a good source rock. The global estimation, based mainly on the reddish-to-gray groundmass, varies between Indices 2 and 3 . This fluorescence is caused by diffuse sapropelic (algal) matter (Robert, 1979) impregnating an argillaceous ooze. There is very little detritic quartz in Core 27, and some calcite occurs in Core 47.

Numerous organisms occur and are visible in white light, but their fluorescence coloration varies with depth. Thus, because of thermal alteration, all samples (except that from Core 47) are very rich in diatoms (Plate 1) and deserve the name diatomaceous ooze. Diatoms probably compose more than $90 \%$ of the sample. Most organic matter probably originates from diatom protoplasm.

Monocellular algae are present, but not abundant, in two samples (Cores 27 and 47); dinoflagellate cysts are common in Core 37 and form continuous beds; pine pollen occurs in Cores 3, 17, and 27.

The sample from Core 47 is pure shale without diatoms, and the groundmass fluoresces gray.

Diatoms fluoresce strongly green in Core 3, weakly in Core 13, and not at all below. The fluorescence color is the same as the cellulose coloration, and it defines quite well the fine structure of the organisms. An attempt to destroy cellulose by dissolving it in the Schweitzer liquid was ineffective, probably because of the opal protection of the test. The absence of this fluorescence in the hole correlates with the changing coloration of pine pollen (green in Core 3; yellow in Core 17). These color variations by thermal alteration are well known (Ottenjann et al., 1974). Correlatively, spores and dinoflagellates are yellow in Samples 479-37-5, 130-150 cm and 479-47-4, 110-130 cm; unicellular algae are yellow and dark yellow in Samples 479-27-4, 120-140 cm and 479-47-4, $110-130 \mathrm{~cm}$.

The absence of this questionable cellulose is well known for lignites under thermal evolution in coal basins (Stach et al., 1975).

The palynological study confirms most of our previous observations. In all the samples, the TOM slides show an amorphous material made up of large yellowbrown flaky masses with no definite shape. They also contain abundant small crystals of pyrite. This amorphous material corresponds to more massive and darker flakes with more accurate margins in Samples 479-37-5, $130-150 \mathrm{~cm}$ and $479-47-4,110-130 \mathrm{~cm}$.

The palynological slides (IOM) show the predominance of sapropelic amorphous material in yellow flakes of small-to-medium size. The change in color is caused by the disaggregation of pyrite. The disaggregation of the large flakes in TOM has produced tiny globular particles $(<1 \mu \mathrm{m})$, small-to-medium sized flakes, and transparent "membranes." This proves that the flakes comprise more-or-less dense and polymerized matter and material soluble in alcohol-bromide. The treatment causes the appearance of a few ligneous, terrigenous particles (light brown or opaque). Microfossils are also sometimes abundant, as, for example, in Samples 479$13-1,110-130 \mathrm{~cm}$ and $479-17-5,120-140 \mathrm{~cm}$ (angiosperms) and in Samples 479-27-4, 120-140 cm and 479$37-5,130-150 \mathrm{~cm}$ (gymnosperm pollen grains [pinus] and dinoflagellate cysts). The TAI values are low (1.5$2^{-}$) but higher in Sample 479-47-4, 110-130 cm (2+). Sample 479-37-5, 130-150 cm has a lower maturation index because of transparent dinocysts. The higher value in Sample 479-47-4, 110-130 cm could be correlated with denser and darker flakes, which would thus be caused by a higher degree of maturation.

In sum, the samples comprise highly fluorescent, sapropelic groundmasses and amorphous palynofacies, generally corresponding to potential hydrocarbon source rocks. The geochemical results indicate satisfactory hydrogen indices (about 300-400). In good agreement is the strong fading effect in fluorescence (Plate 1), though negative, due to the low maturation.

The progression of maturation is shown by the variations in fluorescence (as explained in the column of observations on the nature of organic matter) and the palynological TAI. Such a relatively high diagenesis, not far from the onset of oil generation, is exceptional in such a recent and shallow section and is probably related to the rift-heated location in the Gulf of California.

\section{Site 478}

The Holocene sediment in Sample 478-7-5, 120-140 $\mathrm{cm}$ is very similar to Sample $479-3-2,112-130 \mathrm{~cm}$. The diatomaceous ooze fluoresces strongly green and the shaly groundmass fluoresces dark red (Index 3). Vitri- 


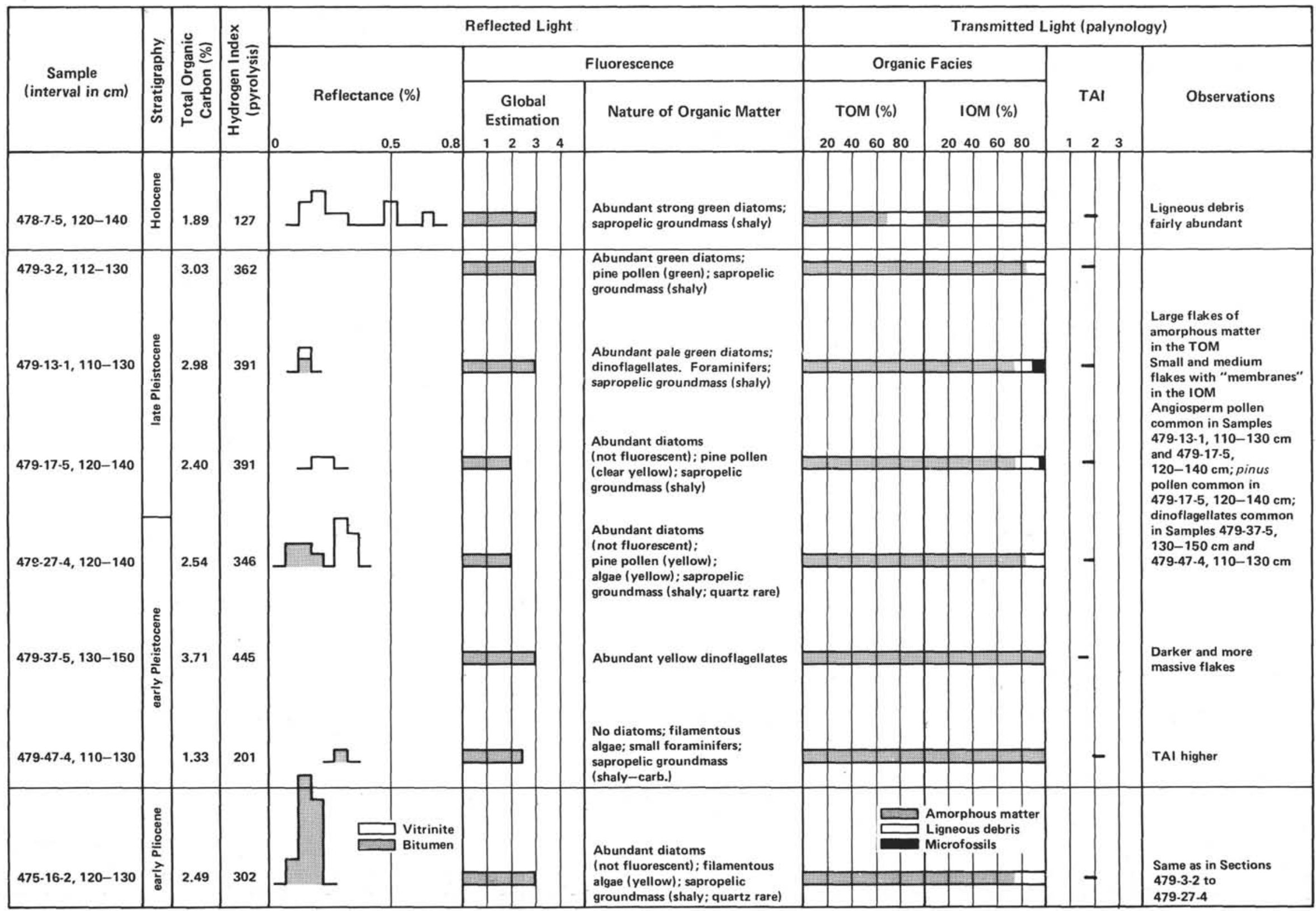

Figure 6. Synopsis: optical analysis of organic matter. 
nites, more common than in the Hole 479 sample, produce dispersed reflectances $(0.15-0.65 \%)$ because of reworked material. The youth, shallow burial, and fluorescence of diatoms indicate that maturation is low (or absent).

The palynological study of Sample 478-7-5, 120-140 $\mathrm{cm}$ emphasizes characteristic differences with the palynofacies in Hole 479 . The Hole 478 sample contains mixed palynofacies. In the MOT slide, the amorphous material makes up $10 \%$ of the total, whereas the inherited terrigenous material is abundant (up to $30 \%$ ).

In the IOM palynological slide, the ligneous material is common and correlates with the presence of vitrinite (light-brown and dark particles [tracheids, ligneous tissues, and fibers]). Abundant Pinus pollen grains occur together with angiosperm pollen and dinoflagellates. The amorphous matter comprises small flakes.

These observations (Fig. 6) confirm the difference in geochemical data between the Hole 479 samples and the Hole 478 sample. The hydrogen index, much lower than for the Hole 478 sample, correlates with the high content of terrigenous woody remains. The terrigenous remains could be caused, in part, by reworking. The TAI value is low (about 2).

\section{Site $\mathbf{4 7 5}$}

Sample $475-16-2,120-130 \mathrm{~cm}$ (early Pliocene) is similar to the deepest samples in Hole 479. Diatoms abound but do not fluoresce, some filamentous algae are yellow, and the sapropelic groundmass (shaly; rare quartz) has a good brown-red fluorescence. One peculiarity is the presence of bitumen with low $(0.2 \%)$ reflectance-not a reliable indicator of maturation. Fluorescence observations suggest a certain thermal maturation, and the presence of bitumen confirms the generation of hydrocarbons; but its reflectance underestimates the true degree of thermal evolution.

The TOM and IOM palynological slides show the same palynofacies and TAI as in Samples 479-3-2, 112$130 \mathrm{~cm}$ through $479-27-4,120-140 \mathrm{~cm}$.

The samples from Holes 478 and 475 are good controls for observations on the nature of organic matter and maturation in the Hole 479 sample. The composition of the organic matter agrees with the geochemical results (see HI, Fig. 6).

\section{CONCLUSIONS}

The organic matter in Pleistocene and lower Pliocene marine hemipelagic and diatomaceous mud or ooze overlying igneous material in Holes 474A, 475, 476, 478,479 , and $481-481 \mathrm{~A}$ is commonly marine and derived mainly from diatoms. Its range is immature, but diagenetic effects with depth are obvious and can be related to the active rifting. Terrigenous immature organic material is also present, particularly near the eruptive contact in Holes $474 \mathrm{~A}$ and 478 or at the top of mudflows in Hole 481A.

\section{ACKNOWLEDGMENTS}

The authors are indebted to A. Hood and B. R. T. Simoneit for reviewing the manuscript.

\section{REFERENCES}

Debyser, Y., and Gadel, F., 1979. Geochimie des kérogènes dans les sédiments. Géochimie Organique des sédiments marins profonds, Orgon III: Paris (Editions CNRS), pp. 375-403.

Espitalié, J., Laporte, J. L., Madec, M., et al., 1977. Méthode rapide de caractérisation des roches mères, de leur potentiel pétrolier et de leur degré d'évolution. Rev. Inst. Fr. Pet., 32:23-42.

Huc, A. Y., and Durand, B., 1977. Occurrence and significance of humic acids in ancient sediments. Fuel, 56:73-89.

Huc, A. Y., Durand, B., and Monin, J. C., 1978. Humic compounds and kerogens in cores from Black Sea sediments, Leg 42B-Holes 379A, B, and 380A. In Ross, D. A., Neprochnov, Y. P., et al., Init. Repts. DSDP, 42, Pt. 2: Washington (U.S. Govt. Printing Office), 737-748.

Ottenjann, K., Teichmüller, M., and Wolf, M., 1974. Mesures spectrales de fluorescence sur sporinites en lumière réfléchie, une méthode microscopique de détermination du rang des charbons peu houillifiés. Fortsch. Geol. Rheinl. Westfalen, 24:1-184 (French translation BRGM 5477).

Robert, P., 1979. Classification des matières organiques en fluorescence. Application aux roches méres pétrolières. Bull. Cent. Rech. Explor. Prod. Elf-Aquitaine, 3:223-263.

Stach, E., Mackowsky, M. Th., Teichmüller, M., et al., 1975. Stach's Textbook of Coal Petrology: Berlin (Gebrüder Borntraeger).

Teichmüller, M., and Ottenjann, K., 1977. Liptinite und Lipoide Stoffe in einem Erdölmuttergestein. Erdoel Kohle, 9:387-398.

Tissot, B., Durand, B., Espitalié, J., et al., 1974. Influence of the nature and diagenesis of organic matter in the formation of petroleum. Am. Assoc. Pet. Geol. Bull., 58:499-506.

Tissot, B., Deroo, G., and Herbin, J. P., 1979. Organic matter in Cretaceous sediments of the North Atlantic: Contribution to sedimentology and paleogeography. In Talwani, M., Hay, W., and Ryan, W. B. F. (Eds.), Deep Drilling Results in the Atlantic Ocean: Continental Margins and Paleoenvironment: Washington (American Geophysical Union), pp. 362-376. 

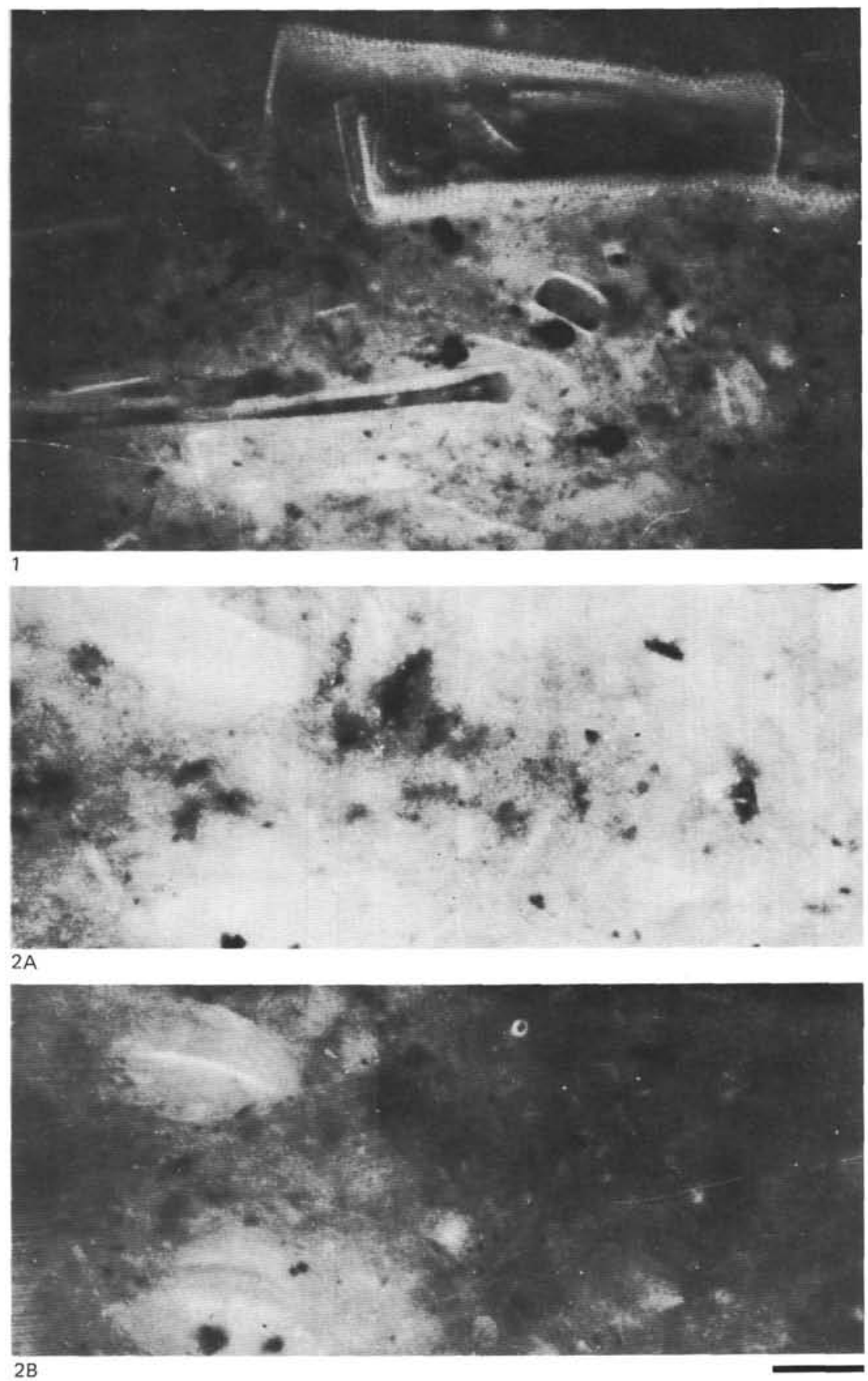

Plate 1. Fluorescence of Sample 479-3-2, 112-130 cm. (Scale bar $=50 \mu \mathrm{m}$.) 1. Fluorescent (red) groundmass and fluorescent (green) diatoms. 2. Fading fluorescence in the groundmass: $\mathrm{A}=$ before exposure. $\mathrm{B}=$ after exposure $(2 \mathrm{hr}$.) of the right half. 

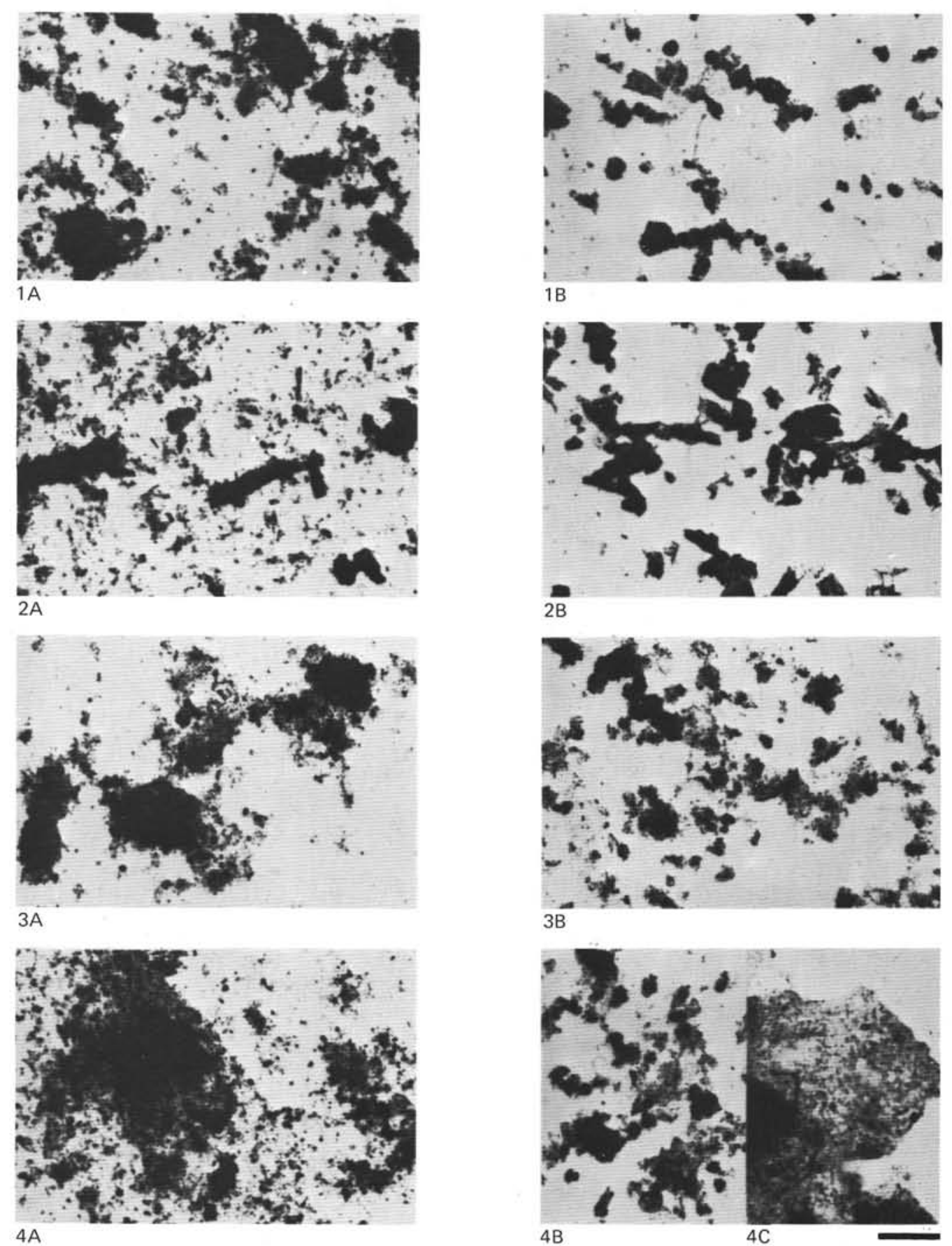

Plate 2. Palynofacies from Holes 475,478 , and 479. (Scale bar $=100 \mu \mathrm{m}$, except where noted; TOM $=$ total organic material, IOM $=$ insoluble organic material). 1A. Sample 475-16-2, 120-130 cm (TOM). 1B. Sample 475-16-2, 130-130 cm (IOM). 2A. Sample 478-7-5, 120-140 cm (TOM). 2B. Sample 478-7-5, 120-140 cm (IOM). 3A. Sample 479-37-5, 130-150 cm (TOM). 3B. Sample 479-37-5, 130-150 cm (IOM). 4A. Sample 479-47-4, 110-130 cm (TOM). 4B. Sample 479-47-4, 110-130 cm (IOM). 4C. Sample 479-47-4, 110-130 cm (IOM; scale bar = 20 $\mu \mathrm{m}$ ). 